\title{
POTENTIAL BARRIERS IN IMPLEMENTING LOCAL-FOOD-BASED COMPLEMENTARY FEEDING PRACTICE
}

\author{
Asmaripa Ainy, ${ }^{*}$ Misnaniarti, Fatmalina Febry, Dian Safriantini \\ Faculty of Public Health Sriwijaya University, Jl. Palembang-Prabumulih KM 32 Ogan Ilir, 30662, \\ Indonesia
}

\begin{abstract}
Local-food-based complementary feeding (LFBCF) practice may be an important approach in the growth and development of children aged 6 to 24 months. This study aimed to describe potential barriers in implementing local food-based complementary feeding practices among mothers in Banyuasin regency, Indonesia. A qualitative study was conducted by using 24 semi-structured interviews and a focus group discussion. Participants were 24 mothers with children aged 6 to 24 months in Banyuasin Regency, Indonesia that recruited purposively. Data were analyzed using thematic analysis. The majority of the mothers were 20-30 years old. All participants have implemented LFBCF practice because local food ingredients are easy to find locally at an affordable price. Community cadres assisted village midwives in integrated health post service such as disseminating information concerning local food recipes and facilitating information exchange among mothers regarding complementary feeding practice. Three main emerged themes identified from this study were: mother's knowledge about local food recipes, mother's knowledge about healthy complementary food preparation, child-eating behavior. Improving the nutritional status of children starts with the family by motivating mothers to provide complementary foods, which also requires the support of local cadres.
\end{abstract}

Keywords: barriers, cadres, complementary feeding, local foods, mother

\begin{abstract}
ABSTRAK
Praktek Pemberian makanan pendamping ASI (MP-ASI) yang terbuat dari bahan lokal merupakan pendekatan penting dalam tumbuh kembang anak usia 6 sampai 24 bulan. Tujuan penelitian ini adalah untuk mendeskripsikan hambatan potensial dalam penerapan MP-ASI pada ibu-ibu di Kabupaten Banyuasin, Indonesia. Studi kualitatif dilakukan dengan menggunakan 24 wawancara semi terstruktur dan diskusi kelompok terarah. Informan adalah 24 ibu yang memiliki balita usia 6 hingga 24 bulan di Kabupaten Banyuasin, Indonesia yang dipilih secara purposif. Analisis data menggunakan analisis tematik. Mayoritas ibu berusia 20-30 tahun. Semua peserta sudah menerapkan praktek pemberian MP-ASI local karena bahan pangan lokal mudah ditemukan di daerah setempat dengan harga yang terjangkau. Kader masyarakat mendampingi bidan desa dalam pelayanan posyandu seperti sosialisasi resep makanan daerah dan memfasilitasi pertukaran informasi antar ibu tentang praktek pemberian MP-ASI. Tiga tema utama yang yang diidentifikasi dari penelitian ini adalah: pengetahuan ibu tentang resep makanan lokal, pengetahuan ibu tentang penyiapan MP-ASI sehat, dan perilaku makan anak. Peningkatan status gizi anak dimulai dari keluarga yakni dengan memotivasi ibu dalam praktek pemberian MP-ASI dan tentunya hal ini juga memerlukan dukunga kader setempat.
\end{abstract}

Kata Kunci: hambatan, kader, MP-ASI, makanan lokal, ibu,

Correspondece Address: Asmaripa Ainy, Faculty of Public Health Sriwijaya University, Jl. Palembang-Prabumulih KM 32 Ogan Ilir, 30662, Indonesia,E-mail: asny_plbg@yahoo.com 


\section{Introduction}

Children are considered to be the potential human resources of both developed and developing countries. Malnutrition issues among children cause major morbidity and mortality. Several previous research documented malnutrition occurrence in developing countries include Indonesia ${ }^{1,2,3,4}$. World Health Organization (WHO) stated that malnutrition deficiencies, excesses, or imbalances in a person's intake of energy and nutrients include undernutrition (wasting, stunting, underweight), inadequate vitamins or minerals, and overweight ${ }^{5}$.

Infants between 6 to 24 months of age need complementary feeding along with breast milk. Complementary feeding is important for supporting the healthy growth and development of children. Research in Kenya recommended improving nutrition knowledge to caregivers on optimal use of locally available complementary feeding ${ }^{6}$. Local food may be an important approach in providing cheap and affordable complementary feeding of children aged 6 to 24 months. There are limited studies on barriers to complementary feeding of children aged 6 to 24 months. The results of this research will be beneficial for the health planning and policy in increasing feeding practices at both national and local levels. Therefore, this study aimed to describe potential barriers in implementing local food-based complementary feeding practices among mothers in Banyuasin Regency, Indonesia.

\section{Method}

This study was undertaken in Sukajadi, Suak Tapeh and Pangkalan Balai sub-district. These regions are part of the Banyuasin region in South Sumatera Province, Indonesia, with a population of 822.575 persons. It was descriptive research with a qualitative approach that was conducted between June and August 2018. The study informants were mothers with children 6-24 months of age in the sub-district areas of Sukajadi, Suak Tapeh and Pangkalan Balai. Researchers ensured that the children are still given breast milk in addition to complementary foods Selecting participants based on discussion with local health centers and local midwives.

Qualitative interview in this study is a method to explore insight and experience of 24 mothers of children aged 6-24 months regarding complementary feeding practices using semistructural in-depth interviews. Semi-structural in-depth interviews are open questions appropriate with the interview guide. The interviewer has a chance to probe additional questions, but the interview guide illustrates clear instructions on what kind of topics should be obtained.

Written consent from all informants was gained before the interviews process. All the information obtained during the study was treated as confidential and used for the purpose of the study only. The questionnaires comprised mainly of general profiles on mothers and children 
include mother's age, children age and sex. Moreover, one focus group discussion (FGD) was conducted. Informants of this FGD were six mothers who have participated in previous interviews. Guidance for FGD was administered based on interesting and important findings from interviews on possible barriers in implementing local complementary feeding practices.

Data analysis used thematic analysis to identify regular patterns of meaning regarding the important emerging issues pertaining to local-based complementary feeding practice. All respondents were informed of the study purpose.

This study was reviewed and accepted by the ethical committee of Fakultas Kesehatan Masyarakat Universitas Sriwijaya with letter number: 209/UN9.1.10/KKE/2018.

\section{Results}

Banyuasin regency is a district in South Sumatera province in Sumatera Island. Currently, Banyuasin Regency consists of 19 sub-districts with 304 villages/urban villages. With a total of 288 villages and 16 urban villages ${ }^{7}$.

\section{Characteristics of Informants}

Informants of this study were 24 mothers of children aged 6-24 months. We were collecting data through semi-structural in-depth interviews. Table 1 explained the three-quarter of the mothers were $20-30$ years old ( $75 \%$ ). Moreover, the majority of the children were boys (75\%) and only $25 \%$ of the children were girls. More than half of the children were of age group 12-24 months (66,7\%), the minorities of the children were of age group 6-8 months $(12,5 \%)$.

Table 1. Informants Profile

\begin{tabular}{lc}
\hline Characteristics & $\mathbf{n ~ ( \% )}$ \\
\hline Mother Age (years) & $18(75 \%)$ \\
$20-30$ & $6(25 \%)$ \\
$31-40$ & \\
Child Age (Months) & \\
6-8 & $3(12,5 \%)$ \\
$9-11$ & $5(20,8 \%)$ \\
$12-24$ & $16(66,7 \%)$ \\
Child Sex & \\
Boy & $18(75 \%)$ \\
Girls & $6(25 \%)$ \\
\hline
\end{tabular}

\section{Complementary Feeding Practices by Mothers}

All mothers informed that they initiated complementary foods for their children after six months. Their children consumed a lot of portions of the carbohydrate besides proteins, vegetables, 
and fruits due to affordability. The children consumed mainly rice porridge with small pieces of freshwater fish or egg every day. Several children also were being fed with formula milk or instant cereals. Some children did not want to eat the same kinds of food every day. All mothers reported that they served children meals three times per day. Some mothers then stated that they gave breastfeeding without anxiety concerning breast milk volume reduction. All participants agreed to implement local complementary feeding because local food ingredients are easy to find in the local area at an affordable price.

\section{Local Food Based Complementary Feeding Practices and Its Barriers}

This study showed that complementary feeding in the three sub-districts of Banyuasin consists mainly of staple food such as rice porridges, as quoted in the following interviews:

“...I always give rice porridge to my child every day, usually for lunch.... (Se)"

"Our staple food is rice, so it is easy to make rice porridge as a complementary food. I add mashed freshwater fish such as catfish or eggs. (Ic)"

"Our family eats rice every day. For complementary foods, I cook rice porridge with fish, eggs, tofu or chicken meat. (Dw)"

The interviews with mothers demonstrated rich data relating to complementary feeding practice and its barriers. Three essential themes were yielded, including: 1) mother's knowledge about local food recipes, 2) mother's knowledge about healthy complementary food preparation, and 3) child eating behavior. Furthermore, five barriers that often occur in the provision of complementary foods by mothers in Banyuasin regency also to be gained from the FGD, namely: 1) obtaining healthy and balanced nutrition local complementary feeding recipes; 2) children rejection of local complementary feeding; 3) variety of family meals which children can consume; 4) cleanliness of cooking utensils and food materials; and 5) child's appetite is sometimes not good. The information obtained from the FGD indicated that mothers were very enthusiastic when conveying the recipe variety of complementary foods and the child's interest in the prepared food.

\section{Mother's Kowledge About Local Food Recipes}

Mothers in Sukajadi, Suak Tapeh and Pangkalan Balai explained that their children have no specific local foods. In general, mothers wanted to provide various complementary foods because it is important to prepare diverse complementary foods for offering balanced nutrient intake. An interesting result from this study was that locally available, nutritious foods such as rice, corn, cassava, soybeans, green beans, papaya, banana, tomato, snake bean, spinach, catfish, egg and 
chicken meat were considered beneficial for cooking complementary feeding. This was shown in the following interview result:

"...I do not restrict my child by eating certain foods. In addition to the rice porridge that I provide every day, I also give mashed banana or cassava alternately. (Mm)"

"In making complementary foods, I usually use local food ingredients such as corn, vegetables like spinach, tomatoes and I also add fish or chicken meat. (Rs)"

The mothers clarified that their knowledge about recipes of complementary feeding preparation from local ingredients was still restricted. They usually get complimentary food recipes through information from family, friends, neighbors, and cadres at health posts and internet sites or social media. The results of interviews with the informants gained general information as follows:

"I often ask my families and friends who also have a toddler about their experience of ingredients in making local complementary foods. They inform me of the recipes through chatting or directly talking. (Su)"

"I get recipes of local complementary foods from close neighbors. Sometimes I look for complementary feeding information from internet sites. I choose suitable recipes for my child's preference. (Rn)"

"Every month, I take my child to the health post and meet community cadre who assist health center workers in conducting health post services such as giving information about the type of complementary feeding and several local complementary food recipes. (Yr)"

\section{Mother' Knowledge About Healthy Complementary Food Preparation}

Infectious diseases are a causal factor for the physical growth of infants. Foods, therefore, should be cooked in a safe method to avoid contamination with microbial pathogens. Complementary foods should be stored hygienically and using of cooking utensils should be clean. Moreover, both the mother's hands should be washed before food preparation. These are supported by the following interview quotations:

"I always wash my hands before cooking complementary foods. In my opinion, hand hygiene is important because dirty hands can cause disease in children. (Ta)" 
"The cleanliness of cooking utensils, bowls, plates, spoons and hands must be considered before cooking complementary foods. (Sa)"

\section{Child Eating Behavior}

Mothers in this study argued that children should be fed patiently in a good situation. They tried to minimized distractions during mealtime to increase children's interest in complementary feeding. Mothers said that children sometimes refuse complementary foods. They persuade children to eat in proper ways, such as: tell them kindly with stories during feeding, take children outside to meet other children, and allow them to watch television after meals. This was described from the result of the following interviews:

“...when my child refuses to eat, I take him to my neighbor's home. Then I persuade him tenderly to eat. (Rn)"

"Storytelling and asking to watch cartoons on television are two ways to persuade my child to consume portions of their meals. (Dw)"

\section{Role of Integrated Health Post in Complementary Feeding Practices}

In addition to mothers and family members, cadres of the community may also pay attention to child feeding. Basically, cadres should not make decisions regarding child feeding, but emotional and informational support for mothers is important. Interesting findings from this study that community cadres assisted village midwives in integrated health post service such as disseminating information concerning local food recipes and facilitating information exchange among mothers regarding complementary feeding practice. The following quotations were explained that.

"...of course, I routinely take my child to the health post and obtain valuable information about local complementary food recipes from cadres and other mothers who visit health posts. (Yr)"

"Midwife in health post encourages mothers to be patiently fed their children and shares simple recipes of complementary foods based on experience in providing complementary foods for her child... (Mm)." 


\section{Discussion}

This study depicts the interesting results of the complementary feeding practice by mothers in Banyuasin Regency and its barriers. The interviews generated a number of interesting results. Generally, complementary feeding practices in three areas of study were satisfactory. All children were given complementary foods besides breast milk after 6 months of age. Other studies revealed that maternal education, residence, and access to media play a part in the timely introduction of complementary feeding to children aged 6-24 months ${ }^{8}$. Though all women implemented the timely introduction of complementary feeding practices, there is still a need to create awareness regarding balanced nutrition complementary feeding. Related to balanced nutrition, the type of local complementary feeding ingredients was an important aspect in implementing complementary feeding by mothers ${ }^{9}$ and local foods availability and access are also essential to be noted because they are related to food security in a household. Previous similar research mentioned that household food insecurity was significantly associated with the dietary diversity of children ${ }^{10}$.

From interviews, the diets of children between 6-24 months mainly comprised of carbohydrates in rice porridge. The nutrient such as vitamins, proteins, and minerals along with the intake of energy are essential in child feeding, growth and development. Rice porridge is a common complementary food given by informants of this study. Different from previous research that maize porridge is a general first food for babies ${ }^{11}$. Complementary feeding has a contribution to child growth and development. The results of the study in Lamreung Village, Darul Imarah District, Aceh Besar, described that there was a significant effect of complementary feeding practice on changes in body weight and children's nutritional status ${ }^{12}$.

It was identified from the FGD that individual factors both mothers and children's aspects as emerging issues on barriers of complementary feeding practices include children interest and preference and mothers' knowledge. Several researchers ${ }^{13,14}$ reported on a mother's knowledge as an important component of appropriate complementary feeding. Previous research explained that the knowledge aspect had a significant correlation with mothers' behaviors in selecting complementary feeding ${ }^{15}$. Education level is also an important factor and it was illustrated in a study that mothers who have high education levels were more likely to have protection to provide healthy complementary foods compared to those who have low education levels ${ }^{16}$. Another similar study emphasized that educating mothers in the health facility and in the community on the importance of adhering to the recommended age of introducing complementary feeding, meal frequency, and dietary diversity ${ }^{17}$. Also, the role of health professionals in providing information to mothers on appropriate complementary feeding during prenatal, delivery, postnatal, and immunization services are needed ${ }^{18}$.

A similar study mentioned several barriers and facilitators, including individual and system-level factors in complementary feeding practice ${ }^{19}$. To improve local complementary 
feeding practice, it is necessary to assist mothers in dealing with barriers to feed their infants adequate and suitable complementary foods. A recent study recommended how to educate mothers concerning appropriately use local ingredients for cooking complementary feeding for their children by community health volunteers or cadres ${ }^{20}$. Knowledge and skills of cadres in complementary feeding preparation is important to be improved related to increase knowledge of mothers during integrated post (posyandu) activities ${ }^{21}$. Besides, cadres could explain the importance of observing the growth and development of children at the posyandu ${ }^{22}$. Furthermore, informing local foods to decrease the dependence in buying instant complimentary foods requires active roles of other related sectors. Nutritionists at the health center (puskesmas) and village midwives play an important role in implementing the policy of providing local complementary foods for the malnourished child ${ }^{23}$.

Increasing knowledge of mothers and child caregivers is required and it could be conducted through socialization in media. Socialization and complementary feeding practice to mothers and caregivers continuously is very much needed ${ }^{24}$. Socialization of local foods is an alternative effort that can be used to improve the nutritional status of children ${ }^{25}$. The related study mentioned that important to raise awareness and knowledge in improving complementary feeding practices through media to reduce undernutrition ${ }^{26}$. Education campaigns concerning feeding practices should not only to mothers but also for family members who are decision-makers like a mother-inlaw or older adult in the family ${ }^{27}$.

This is a qualitative study. Thus, the results cannot be generalized. A quantitative approach would yield better results for generalization. A qualitative is time-consuming, but it gained rich and meaningful data of knowledge and practice on complementary feeding.

\section{Conclusion}

Potential barriers in complementary feeding practice related to mother and child behavior aspects. These barriers were identified, including nutritious food recipes, variety of meals, cleanliness in preparation, and child's appetite. Mother's knowledge about providing adequate nutrition of complementary feeding is essential and the role of community cadres is needed for reducing the barriers. Given that early childhood is an important period in improving children's growth and development. Moreover, appropriate interventions through effective coordination with related parties. Further investigation about how to make effective coordination among all related sectors is needed.

\section{Acknowledgement}

The authors are grateful to the health office of Banyuasin district for allowing this research. 


\section{Funding}

This research was supported by a grant from Sriwijaya University in 2018.

\section{Conflict of Interest}

The authors declare no conflict of interest.

\section{References}

1. Kramer, C. V., \& Allen, S. Malnutrition in developing countries. Paediatrics and Child Health (United Kingdom). 2015. 25(9), 422-427.

2. Gebre A, Surender Reddy P, Mulugeta A, Sedik Y, Kahssay M. Prevalence of Malnutrition and Associated actors among Under-Five Children in Pastoral Communities of Afar Regional State, Northeast Ethiopia: A Community-Based Cross-Sectional Study. J Nutr Metab. 2019;2019.

3. De Silva I, Sumarto S. Child Malnutrition in Indonesia: Can Education, Sanitation and Healthcare Augment the Role of Income? J Int Dev. 2018;30(5):837-64.

4. Hanandita W, Tampubolon G. The double burden of malnutrition in Indonesia: Social determinants and geographical variations. SSM - Popul Heal. 2015;1:16-25.

5. World Health Organization (WHO). malnutrition. Available at https://www.who.int/newsroom/fact-sheets/detail/malnutrition. accessed 21 March 2020

6. Kimiywe J, Chege P. J Appl Biosci. Complementary feeding practices and nutritional status of children 6-23 months in Kitui County, Kenya. 2015;85(1):7881.

7. Dinas Kesehatan Banyuasin. Profil Kesehatan Kabupaten Banyuasin. 2016.

8. Khokhar S, Jatoi H, Lassi Z. Prevalence of timely introduction of complementary feeding and its related factors in children 6-24 months of age in Hyderabad, Pakistan. Nurs Midwifery Stud. 2017;6(3):115.

9. Ainy A, Misnaniarti, Febry F, Safriantini D. Mother's knowledge regarding local-based complementary feeding for supporting healthy Indonesia program with family method. Int $\mathbf{J}$ Recent Technol Eng. 2019;8(2 Special Issue 9):930-3.

10. Abebe Z, Tariku A, Bikes GA, Wassie MM, Gonete KA, Awoke T, et al. Poor child complementary Feeding Practices in northwest Ethiopia: Finding from the Baseline Survey of Nutrition Project, 2016. Ital J Pediatr. 2019;45(1):1-7.

11. Sayed N, Schönfeldt HC. A review of complementary feeding practices in South Africa. South African J Clin Nutr. 2018;0(0):1-8.

12. Iskandar I. Pengaruh Pemberian Makanan Tambahan Modifikasi Terhadap Status Gizi Balita. AcTion Aceh Nutr J. 2017;2(2):120. 
13. Paudel RK, Basaula YN, Tiwari S. Knowledge and practice of Mothers of under Two Years Children On Complementary Feeding At Bharatpur Hospital, Chitwan, Nepal. J Adv Acad Res. 2018;4(1):111-6.

14. Dad F, Habib I. Mother 's Knowledge , Attitude and Practices ( KAP ) Regarding Complementary Feeding for Children Age 06-24 Months in Kurrum Agency of FATA Pakistan. Public Heal Prev Med. 2017;3(6):33-42.

15. Pradanie R, Rachmawati PD, Cahyani MD. Factors associated with mothers' behaviors in selecting complementary feeding in Surabaya, Indonesia. Nurse Media J Nurs. 2020;10(3):306-16.

16. Shaluhiyah Z, Kusumawati A, Indraswari R, Widjanarko B, Husodo BT. Pengetahuan, sikap dan praktik ibu dalam pemberian makanan sehat keluarga di Kota Semarang. J Gizi Indones (The Indones J Nutr). 2020;8(2):92-101.

17. Masuke R, Msuya SE, Mahande JM, Diarz EJ, Stray-Pedersen B, Jahanpour O, et al. Effect of inappropriate complementary feeding practices on the nutritional status of children aged 6-24 months in urban Moshi, Northern Tanzania: Cohort study. PLoS One. 2021;16(5 May):1-16.

18. Molla M, Ejigu T, Nega G. Complementary Feeding Practice and Associated Factors among Mothers Having Children 6-23 Months of Age, Lasta District, Amhara Region, Northeast Ethiopia. Adv Public Heal. 2017;2017:1-8.

19. Bazzano AN, Kaji A, Felker-Kantor E, Bazzano LA, Potts KS. Qualitative studies of infant and young child feeding in lower-income countries: A systematic review and synthesis of dietary patterns. Nutrients. 2017;9(10).

20. Tampah-Naah AM, Kumi-Kyereme A, Amo-Adjei J. Maternal challenges of exclusive breastfeeding and complementary feeding in Ghana. PLoS One. 2019;14(5):1-16.

21. Asparian, Perdana SM, Nurdini L. Pemberian Makanan Pendamping Asi Berbasis Kearifan Lokal Di Desa Pondok Meja, Kabupaten Muaro Jambi, Provinsi Jambi. J Salam Sehat Masy. 2020;2(1):19-24.

22. Doren WK, Regaletha TAL, Dodo DO. Evaluasi Program Pemberian Makanan Tambahan Pemulihan (PMT-P) terhadap Status Gizi Buruk Balita di Puskesmas Oepoi Kota Kupang. Lontar J Community Heal. 2019;1(3):111-8.

23. Fadilah F, Darmawansyah D, Seweng A. Implementasi Kebijakan Pemberian Makanan Tambahan (Pmt) Terhadap Jumlah Kasus Gizi Buruk Di Kabupaten Pasangkayu. J Kesehat Masy Marit. 2020;2(1).

24. Hapsari Windayanti, Masruroh C. Pemberian Informasi Tentang Pemberian Makan Bayi dan Anak Usia 0-24 Bulan. Indones J Community Empower. 2019;1(1):23-8.

25. Yulia C. Revitalisasi Pemberian Makanan Tambahan Dan Integrasi Pendidikan Gizi Berbasis Kearifan Lokal Di Sekolah Sebagai Upaya Perbaikan Gizi Anak Usia Sekolah. Media 
Pendidikan, Gizi, dan Kuliner. 2017;6(1):18-33.

26. Ali M, Arif M, Shah AA. Complementary feeding practices and associated factors among children aged 6-23 months in Pakistan. PLoS One. 2021;16(2 February):1-21.

27. Javalkar SR, Aras RY. A study on complementary feeding practices among mothers in urban and rural areas. Int J Community Med Public Heal. 2018;5(3):1162. 